\title{
Reforesting China
}

;D 409

R4

bopy 1

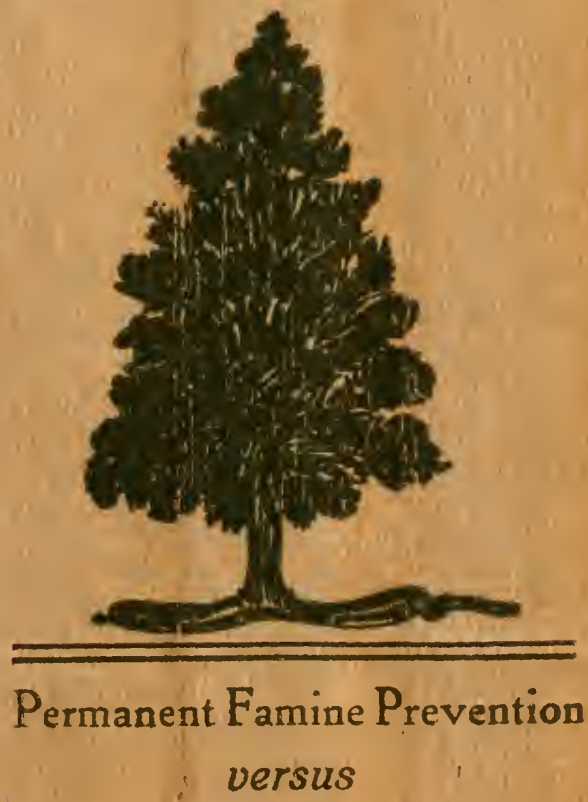

Famine Relief 


\section{thes

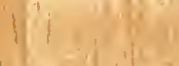

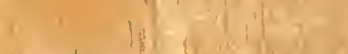
the (c), (in)

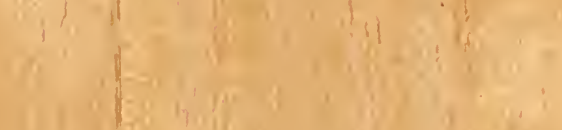

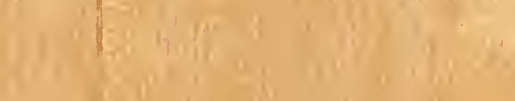
$\operatorname{lig} \frac{1}{10}$ it in

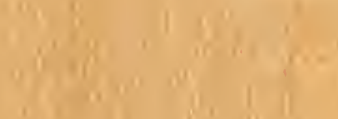

$$
\begin{aligned}
& \text { Iit ing }
\end{aligned}
$$

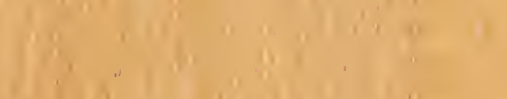

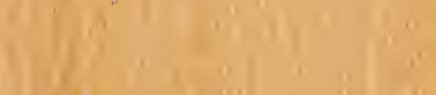

N

1

1'<smiles>[CH]</smiles>

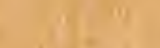$$
9^{2}+x+2 y
$$$$
\text { ily. } x \text { in }
$$

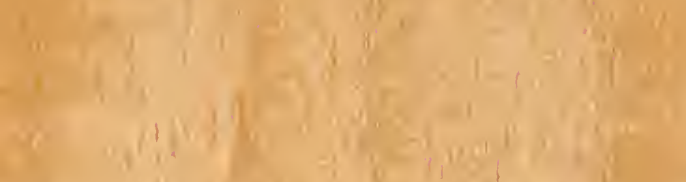

i.

$\lim _{1}$

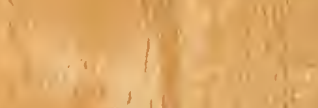

Q., if
$+1.4 / 4=19$
$\{1+1=0$

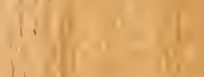
$+13 y$

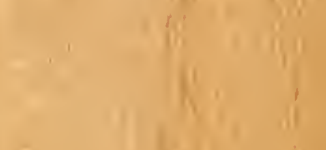

i) 16

7) $i^{1}+1=$

18

$1 \div 9$

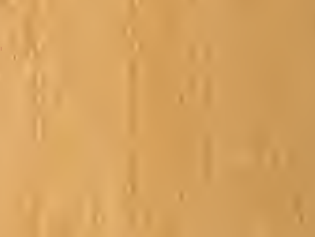

10
11
4
4

a

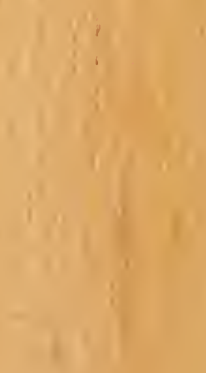

4 


\title{
Reforesting China
}

\section{Permanent Famine Prevention} versus

Famine Relief

\section{By JOHN H. REISNER}

University of Nanking, Nanking, China

\begin{abstract}
A STUDY
under the auspices of the CHINA SOCIETY OF AMERICA
\end{abstract}

International Headquarters :

Thirteen Astor Place, New York City 


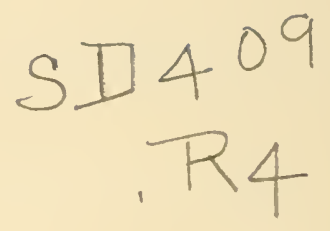

Copyright 1921 by

China Society of America

Printed privately for Members of the Society

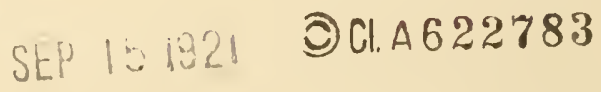




\title{
Reforesting China
}

\author{
Permanent Famine Prevention
}

versus

Famine Relief

There is no substitute for forestry as a factor in the permanent prevention of famines in China. The reforestation of her millions of unwooded acres alone will not prevent famines but there can be no permanent prevention without it.

China's forests are spent, her hills are denuded, an adequate supply of forest products is lacking. Modes of living have had to be adjusted. Her agriculture has been forced to assume responsibility for furnishing fuel to her population, in, addition to food and clothing, making impossible the replenishment of the supply of organic matter in the soil. Fertility and production have been lowered.

The season's rainfall has been dissipated in riotous runoffs, causing ruinous floods. Stream beds on one hand are all but dried up, there being little or no supply of ground water to replenish them by slow regular seepage, while other streams are silted up, unable to carry off the load of soil that has been brought to them from the barren, unproductive hills. Destruction of life and property, and untold suffering have resulted. "Beware of mountain water" read signs in many canyons in China, posted as a warning 
to travelers against the sudden rise of torrents during storms. Agriculture for many has become an all too hazardous occupation.

The people are affected not only economically, their productive efficiency being lessened, but they have suffered physically, and socially as well, where her forests are gone.

China Makes a Beginning in Rcforestation.

After centuries of neglect, China last year spent about a quarter of a million dollars in forestry workplanted about one thousand nurseries, reforested about one hundred thousand acres of otherwise useless land and produced about one hundred million young trees. About one-quarter of her eighteen hundred districts have forest nurseries for the upkeep of which they are taxed. Several of the provinces have developed Provincial Forest Services. Arbor Day is increasing in popularity and its observance is being greatly extended each year. Forestry education is being rapidly developed, until there are now not only forestry schools but forestry is taught in many of the secondary, particularly the agricultural schools.

These facts indicate clearly that China is making progress in her forestry development, that she is beginning to appreciate the need of reforestation and the relation of forests and forest products to her national life.

\section{America Helps.}

America's help in this notable Chinese development is not with money invested directly in forestry projects, but through educational channels. The larger 
share of important forestry enterprises in China to-day, both practical and educational, is in the hands of men trained in the forestry schools of America, or of graduates of American-manned schools in China and the Philippines. There have been twenty-five graduates, and there are now over thirty students enrolled in the forestry course of the College of Agriculture and Forestry of the University of Nanking, an American missionary institution in China.

There are Chinese forestry graduates of Yale, Harvard, Cornell, Syracuse and Michigan. Yale leads the number with more than a half dozen men including their 1921 graduates. Ngan Han, a Michigan graduate, for seven years has been identified with the most important forestry work of the Central Government and is now directing head of the forestry work of the Pekin-Hankow Railway. D. Y. Lin, a Yale man and China's premier forestry propagandist last year organized the Forestry Service for Shangtung Province and has just become director-in-chief of this work.

China's Forestry Development Dependent Upon Chinese.

The future of China's forestry development is very largely in the hands of these Chinese who have come under the influence, directly and indirectly, of American foresters and the advance along forestry lines noted above is due chiefly to the activities of these young men. They have come to know the problems and significance of forestry to China and that the responsibility for adequate forestry developments is their own. 
American Famine Funds of 1913 Permanently Invested.

The Forestry Fund Committee of Shanghai has been the financial sponsor for the education of the Chinese students sent to the Philippines and has provided generously for the forestry work at Nanking, where in addition to paid scholarships they have provided a revolving forestry scholarship loan fund of $\$ 5,000$ and make an annual grant of $\$ 5,000$, Chinese currency. An interesting fact about the Forestry Fund Committee is that it is administering left-over funds from the Hwai River famine relief of 1912-1913. These funds arrived in China too late to be used in relief work and it was decided by the relief committee in charge to use the money to provide permanent relief. It was a wise decision and the plan is already bearing fruit through the work of competent young men in responsible forestry positions throughout China. The returns on this investment in permanent famine relief are increasing rapidly and will be of ever greater value and influence throughout the years.

Forcstry in China Is Developing From the Bottom Up.

Forestry in China is not developing as it has in Western countries. In them the Central Government assumes a very large share of financial control and responsibility. In China it has been more largely by individuals, societies, or companies, districts and provinces. This condition may be expected to continue even in the face of a marked activity on the part of the Central Government. Individuals, companies, and small political units in China will have from the outset a much more important place in reforestation projects than similar bodies have had in the West. 


\section{Famine Prevention Includes Many Factors}

In addition to forestry, there are other important factors which must be recognized as essential to any comprehensive program of famine prevention, such as:

1. River Conservancy.

2. Development of transportation facilities.

3. Underground water supply for irrigation purposes.

4. Distribution of population through colonization.

5. Industrial development.

6. The development of granaries.*

7. The establishment of rural credit and saving societies.

8. Improvements in agriculture.

\section{Reforestation Gives Permancy to Relief Measures}

Watersheds must be reforested if wise conservancy is to be most effective. The water holding capacity of forests provides valuable control of surface runoff of rainfall. The development of coal mines to relieve the fuel shortage and the demands now made on her agriculture for fuel products need timber, which must be either imported at high cost or grown locally. Furthermore, until coal and wood fuel become cheaper than the fuel products of the farm the soil will not be relieved of its present additional burden, for millions of Chinese make their fires of the stalks and

* China for many centuries had a system of granaries very similar to that organized by Joseph for the Egyptians. According to the Honorable Alfred K. Sze, Chinese Minister to the United States, during the years of heavy harvest the excess food products were bought up by the Government and placed in the granaries until needed in years of short production. There were also communal granaries in charge of the village elders with or without official supervision, and charitable granaries maintained and operated purely by charity. 
roots of farm crops. In the construction of railroads and rolling stock and in their maintenance and repair forest products will be in great demand. The improvement of her agriculture and the conditions of living of a large share of the agriculture population are, very directly dependent on an adequate production and supply of forest products.

\section{Popular Education in Reforestation Effective}

\section{Economical}

While all these factors of famine prevention are important, reforestation must be considered basic and can be accomplished by the masses of the people through processes of education-and with a minimum outlay of money. It is evident also, that certain of the factors given can only be handled by Government, not merely because of their political character but because of the huge sums of money which will be involved. There are other factors, however, which can be made to function very largely and more directly through education, and it is such factors that would form a legitimate sphere of activities for American friendly interests. Forestry education particularly is a project which will call forth the hearty co-operation of the Chinese, both officially and individually, and at the same time be wholly free from political impediments.

\section{A Ten-Year Forestry Education Program}

Ten years of modest investment in reforestation would produce powerfully effective results for famine prevention. Such a program should be developed along these lines: 
1. Training of Foresters. - The training of leaders is the first step. A strong group should understand the principles and practices involved in the larger problems of forestry in China. They will provide leadership for Chinese enterprises,-both educational and practical,--which shall at once be national, provincial, corporate and individual in their scope and interest. To provide such training, teachers are obviously required who are capable of interpreting their own knowledge secured in one country or one part of the country in terms of the needs arising out of the conditions under which they find themselves in the new country with a fundamentally different forestry environment. Teaching should be confined to college grade and post-graduate work. Not only would such a forestry training attract many students of their own accord, but it should not be difficult to have students sent by the various provinces on government scholarships.

2. Forestry Extension Work.-Such work should be emphasized. All the following projects can, and should be, carried out simultaneously:

(A) Illustrated lectures with charts and demonstrations ;

(B) Preparation and distribution of bulletins and circulars, both scientific and popular;

(C) Newspaper propaganda. - (An immense amount of excellent publicity can be secured through the Chinese newspapers. This has been demonstrated);

(D) Collection and distribution of tree seeds to schools and nurseries at cost;

(E) The development of school nursery clubs.Thousands of schools could be enrolled, as they have been enrolled for school gardens in the United States. 
Such a development would have a marked effect on the extension of Arbor Day;

(F) Arbor Day which in many places is celebrated as a national holiday and is being more widely observed each year in China, should be furthered;

(G) Extension Forestry course-more particularly courses that would include demonstrations of nursery practices and actual tree planting operations - should be developed. Many of these extension projects could carry at least a good share of their expenses through co-operation with official agencies, particularly travelling expenses in connection with lecture tours in the various provinces.

3. Investigation.-There are numerous investigations along the lines of Forest Botany, Wood Technology, Silvics, Silviculture, Forest Products and Utilization, Management, Forest Finances and the like which should be carried on. Our general knowledge of Chinese Forestry conditions must be reduced to more specific facts and much detail which can only be secured through careful scientifically-conducted investigations. Much of such work can be carried on by teachers, but the services of outstanding forestry investigators should also be made available.

\section{Organization and Staff for Ten-Year Program.}

The organization of the proposed program should be under one administration, connected with an institution which could offer much in the way of supplementary instruction in subjects such as botany, entomology, soils, etc., which are closely allied to technical forestry courses. Facilities should also be offered for teaching and investigation and in the development of extension work. 


\section{China at Work}

To know what China is actually doing in reforesting her hills, will help to give us a better picture of what there is to do, and how the Chinese are going about to do it. The accounts of what Chinese graduates of forestry schools under American administration have done will indicate in what a very real way America is helping China.

Local Officialdom at Work.

The Kao-Yi district of Chihli province has its own nursery, with a budget of $\$ 1,080$ which is raised from local tax on cotton. The second nursery of Shensi province, with three local nurseries under its direction, has a budget of $\$ 2,400$, with a production of five million seedlings. This nursery has adopted the policy of giving free to anyone in their nursery area 50 trees and up to $5 \mathrm{lbs}$. of tree seeds. For larger amounts a slight charge is made. The LinCheng district (Chihli) industrial deputy with his central nursery and four sub-stations, his budget of $\$ 1,350$ raised from house and land taxes, and 3,000 mow of land reforested to date, is planning to have every family plant five trees annually for each male member. The second Chekiang provincial nursery supplies free of cost over a million trees, to 16 districts in addition to schools, farmers and others, from its 190 mow nursery containing more than four million transplants and seedlings, on its budget of $\$ 2,934$ raised from local taxes. Such instances as these can be duplicated many times.

A Yale Forestry School Graduate at Work.

Mr. D. L. Lin, one of the first Chinese graduates of the Yale Forestry School, after returning to China, carried on forestry propaganda (for several years) 
under the auspices of the International Committee of the Y. M. C. A. Then for three years he taught forestry in the College of Agriculture and Forestry of the University of Nanking. While at the University Mr. Lin co-operated with the Governor of Shantung in organizing the Shantung Provincial Forestry Service, and later resigned to become Chief Forester of the Province. Work was prosecuted so vigorously that the first planting season saw the organization of three forestry stations, the establishment of three nurseries with plans for two more for the following season, over 550,000 trees planted on 2,000 mow of land and an additional 3,000 mow of land seeded. The budget calls for about $\$ 22,000$, payable through the Provincial Treasurer.

\section{A Philippine Forestry School Graduate at Work.}

The outstanding forestry development in China continues to be that of the first Kiangsu provincial forestry station started in 1916 and located near the famous Ming tombs at Nanking. Soong Ding-moo, a graduate of the Philippine School of Forestry with twenty-one assistants, two of whom are receiving their forestry education in the Philippines, is at the head of this work. His budget last year was $\$ 34,0.00$, voted by the provincial assembly and paid wholly by the province through the Provincial Department of Finance. 34,000 mow of land ( 1 mow- $1 / 6$ acre) have been replanted to date with two and one-half million of trees. Three nurseries were maintained, with an area of 371 mow carrying 1,275,000 transplants and about 3,000,000 seedlings divided among seventythree different species. Trees and seeds for nurseries and over 50,000 trees for transplanting and for use in the observance of Arbor Day, were distributed to 
one hundred and eighty-six district officials, agricultural societies, and agricultural and forestry stations and companies or individuals. There are three substations already located in important parts of the province, with two more stations being planned for. Sixteen students are also being given practical training to fit them to go out into the province and develop the same kind of work that is being done at the Central Station.

\section{A University of Nanking Graduate at Work.}

Mr. Peng Ko-chung is Overseer of the forest plantations of the Lunghai Railway. His duties consist of supervising the head nurserymen, gardeners and workingmen, managing the central and four subnurseries, collecting herbian specimens, writing the regular reports, making all purchases of materials needed in the work of the nurseries. The Central Chengchow nursery occupies 900 mow of land. The total number of seed beds, including the four subnurseries, is 3,300, and contain more than three hundred species. Last year about one million seedlings were produced. The expenditure on the nurseries is $\$ 10,000$.

\section{China Is Not a Treeless Country}

China does have some forests, but only because they are largely inaccessible; and there are trees everywhere, even in North China, though very scarce. As a whole, China is not a treeless country by any means. The influence of Buddhist priests has been very great in preserving small wooded areas and tree species which otherwise would have been 
done away with in the general destruction of the forests. Without the few trees in the villages and the evergreens about the graves of the ancestors, North China would be infinitely less inviting than it is. But the presence of a few trees only mitigates what would otherwise be a calamitous situation and the need of reforesting her millions of barren acres persists.

\section{Reforestation Is a Good Investment}

Looked at from almost any standpoint the reforestation of China's denuded areas would be a good investment. If there were no other considerations it would be attractive as a financial investment. From a social standpoint there is probably no one thing that will have a greater effect on raising standards of living in North China particularly utilizing large areas of land suited to no purpose other than forestry, and providing employment to millions of people than an adequate and cheap supply of forest products. This will affect commerce and trade. With her forests renewed, China will be a better place to live in. No less important, reforestation will not only ameliorate but will help permanently in the prevention of famines by relieving agriculture and indirectly effecting fertility and production of the soil, by supplementing river conservancy measures, and influencing the surface runoff of rainfall, increasing the moisture capacity of the soil and greatly lessening the frequency and severity of floods and their consequences. 


\section{Co-Operating in Reforesting China Provides Against the Necessity of Flood and Famine Relief}

Undoubtedly it was a good investment to bring relief to China during the recent famine. Would it not be an infinitely better investment, not particularly for what we could get out of it, but from the standpoint of the opportunities for friendly service to work together with China in the development of preventive measures against the too-oft recurring calamity of floods and famines which befall her? A very small investment on the part of America would add tremendously to the impetus which is now developing in China toward meeting the needs and solving the problems of reforestation, as a chief means to permanent famine prevention and providing against the necessity of famine relief.

The nation that helps China reforest her naked hills will be a friend indeed.

Note.-This discussion refers more particularly to North China, where serious floods and famines have occurred most often. It does not refer to China as a whole though many statements so apply.-J. H. R. 

$60 y=1$

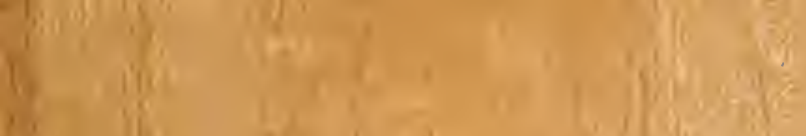

(4. If (2.

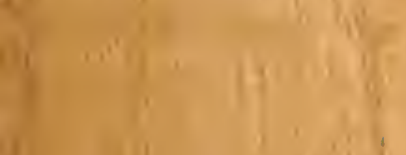

(1)

I.

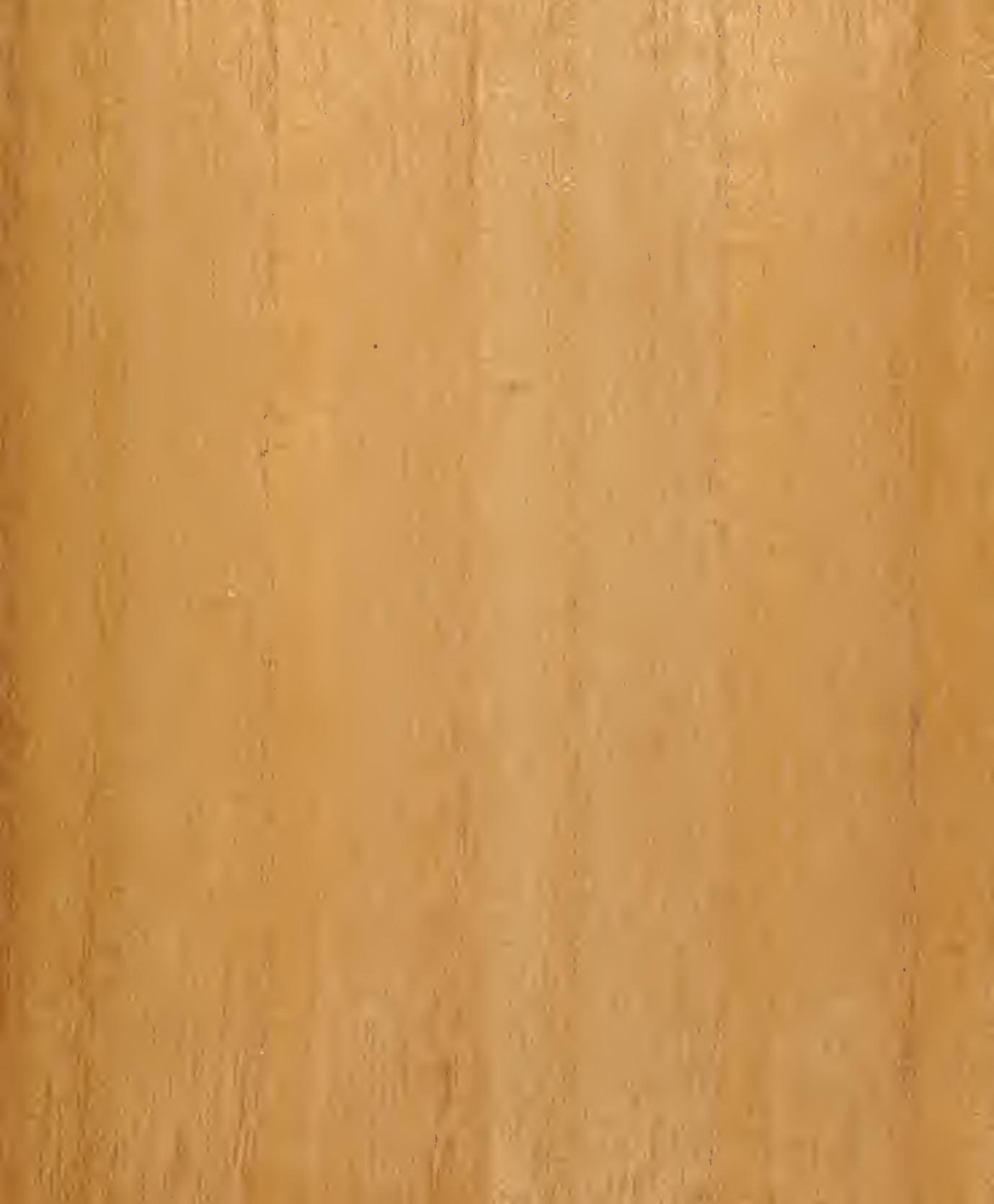

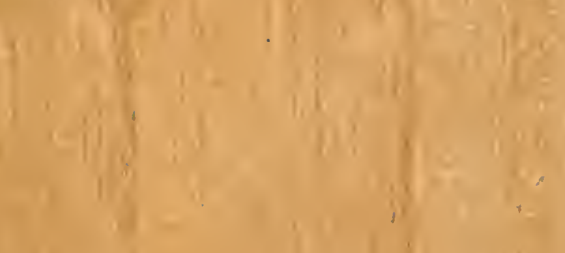

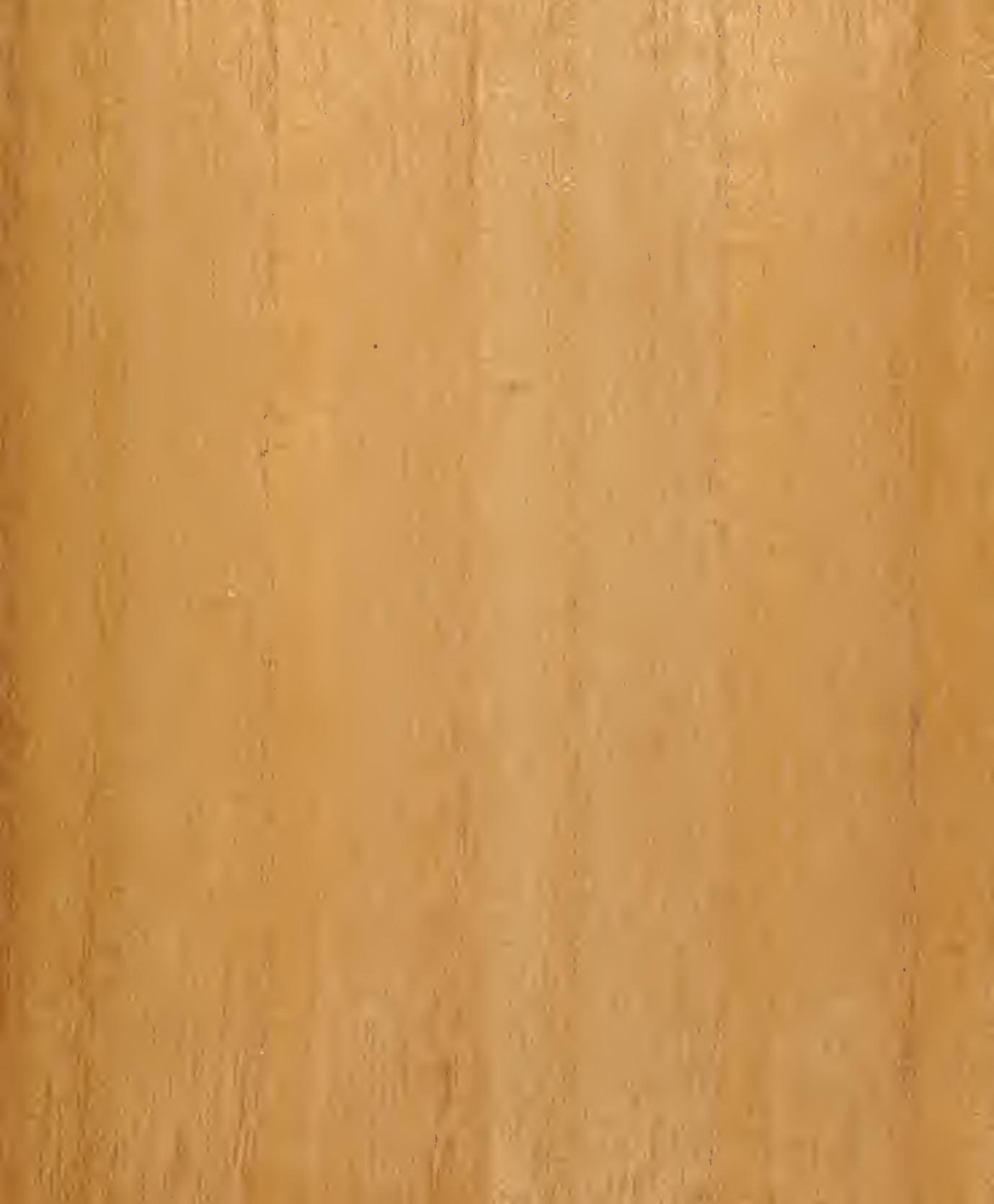

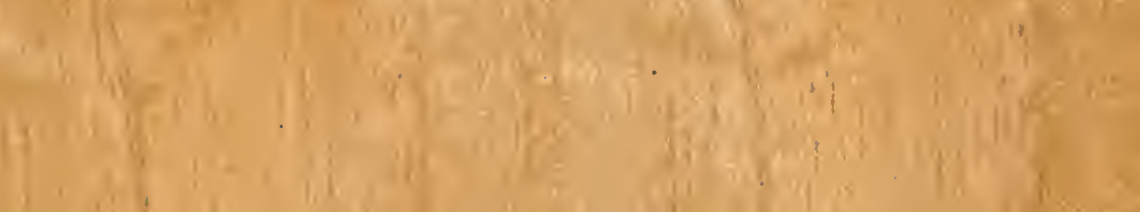

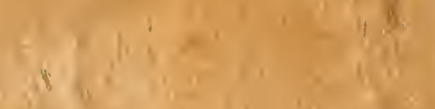
$\frac{1}{2}$ (1) $\times 1=$ $40: \div 1$

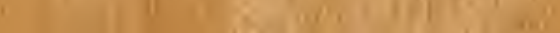
$\gamma$ 


\section{LIBRARY OF CONGRESS}

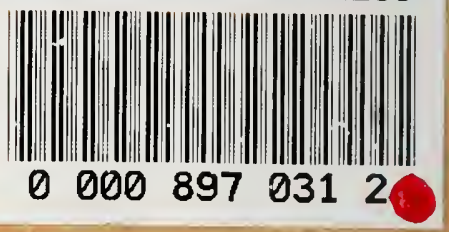

